\title{
Polioencephalomalacia in ruminants from the semi-arid region of Rio Grande do Norte, Brazil
}

\section{Polioencefalomalácia em ruminantes na região semiárida do estado do Rio Grande do Norte, Brazil}

\author{
Antônio Carlos Lopes Câmara ${ }^{1}$; Jael Soares Batista²; Benito Soto-Blanco ${ }^{3 *}$
}

\begin{abstract}
The present study aimed to describe epidemiological, clinical, laboratorial, and pathological findings of polioencephalomalacia (PEM) in ruminants from the semi-arid region of Rio Grande do Norte, Brazil. A total of seven ruminants (five sheep, one cattle, and one goat) with pathological diagnosis of PEM were included. Four cases were associated with thiamine deficiency, on account of chronic ruminal acidosis caused by diets rich in carbohydrate, with mainly concentrates, ground soybean hulls, and melon. Three ruminants from an outbreak of petroleum poisoning presented macro and microscopic lesions consistent with changes of malacia and edema in deep structures of the brain, as described in ruminants with PEM associated with sulfur intoxication. Major macroscopic changes included congestion of cerebral vessels, edema, and herniation of the cerebellum. The most observed microscopic lesions, among all assessed cases, were laminar and segmental neuronal necrosis at different regions of the brain, spongiosis, nuclear pyknosis, and red nucleus neurons. Cerebrospinal fluid analysis revealed nonspecific alterations, requiring its association with epidemiological, clinical, and pathological findings, as the results described here are similar to those reported in toxic diseases with neurological manifestations, such as botulism. Key words: Livestock. Nutritional diseases. Cerebrospinal fluid. Cerebrocortical necrosis.
\end{abstract}

\section{Resumo}

O presente trabalho objetiva descrever os achados epidemiológicos, clínicos, laboratoriais e patológicos de casos de polioencefalomalácia (PEM) em ruminantes na região semiárida do Rio Grande do Norte. Sete ruminantes (cinco ovinos, um bovino e um caprino) com diagnóstico patológico de PEM foram incluídos. Quatro casos foram associados à deficiência de tiamina devido acidose láctica ruminal crônica por oferta de alimentação rica em carboidratos, destacando-se os concentrados, casca de soja triturada e melão. Três ruminantes de um surto de intoxicação por petróleo apresentaram lesões macro e microscópicas condizentes com alterações de malácia e edema em estruturas profundas do encéfalo, descritas em ruminantes com PEM associada à intoxicação por enxofre. As principais alterações macroscópicas incluíram congestão dos vasos cerebrais, edema e conificação do cerebelo. Em todos os casos avaliados, as lesões microscópicas mais observadas foram a necrose neuronal laminar e segmentar em diferentes regiões do encéfalo, espongiose, picnose nuclear e a presença de neurônios vermelhos. A análise do líquido cefalorraquidiano revelou alterações inespecíficas, sendo necessário sua associação aos achados epidemiológicos, clínicos e patológicos, pois os resultados aqui descritos são semelhantes aos relatados em doenças tóxicas com manifestações neurológicas, como o botulismo.

Palavras-chave: Animais de produção. Doenças nutricionais. Líquido cefalorraquidiano. Necrose cerebrocortical.

\footnotetext{
${ }^{1}$ Dr., Médico Veterinário, Hospital Escola de Grandes Animais da Granja do Torto, Faculdade de Agronomia e Medicina Veterinária, Universidade de Brasília, UnB, Brasília, DF, Brasil. E-mail: aclcamara@yahoo.com.br

2 Prof. Associado, Departamento de Ciências Animais, Universidade Federal Rural do Semi-Árido, UFERSA, Mossoró, RN, Brasil. E-mail: jaelsoares@hotmail.com

${ }^{3}$ Prof. Associado, Departamento de Clínica e Cirurgia Veterinárias, Escola de Veterinária, Universidade Federal de Minas Gerais, UFMG, Belo Horizonte, MG, Brasil. E-mail: benito.blanco@pq.cnpq.br

* Author for correspondence
} 


\section{Introduction}

Polioencephalomalacia (PEM) is a morphological diagnosis for necrosis (malacia) in the gray matter (polio) of the brain (encephalo), and is also known as cerebrocortical necrosis (SANT'ANA et al., 2009b). In 1956, the term PEM was used to designate not only the lesion but also a specific ruminant disease presumably caused by thiamine deficiency (ADAMS et al., 1956). Since then, this term has been used synonymously with this condition in ruminants. However, nowadays, not all cases of PEM are associated with thiamine deficiency, and several other etiologies are involved in the pathogenesis of this lesion (SANT'ANA et al., 2009b). Among these causes, we may highlight manifestations of excess sulfur intake (LONERAGAN et al., 1998; CUNHA et al., 2010, 2011; DELFIOL et al., 2013), salt (OSWEILER et al., 1995; DUARTE et al., 2014), lead intoxication (CEBRA; CEBRA, 2004; LEMOS et al., 2004), and thiamine deficiency (GOULD, 1998; SANT'ANA et al., 2009b; GRAÇA et al., 2010) or analogues, such as amprolium (SANT'ANA et al., 2009a; NOGUEIRA et al., 2010), besides ingestion of plants rich in thiaminase, and acute poisoning by Phalaris spp. and by bovine herpesvirus type-5 (GOULD, 1998; SANT'ANA et al., 2009b).

In Brazil, PEM is predominant in cattle (NAKAZATO et al., 2000; LEMOS et al., 2004; VIEIRA et al., 2007; CUNHA et al., 2010, 2011; RIBAS et al., 2013), although there are also reports in sheep (LIMA et al., 2005; VIEIRA et al., 2007; DUARTE et al., 2014), goats (LIMA et al., 2005), and in buffaloes (GUIMARÃES et al., 2008).

The present study aimed at describing epidemiological, clinical, laboratorial, and pathological findings of ruminants with PEM in the semi-arid region of Rio Grande do Norte (Brazil).

\section{Material and Methods}

Clinical records of ruminants attended from
2009 to 2013 at the Veterinary Hospital, Federal Rural University of the Semi-Arid, were surveyed. The hospital is located in the city of Mossoró, Rio Grande do Norte state, Brazil. Only cases with a conclusive diagnosis of polioencephalomalacia by histopathological examination were selected. The study included seven ruminants (five sheep, one cattle, and one goat) treated in the hospital clinical routine. Epidemiological data, and clinical, laboratory (hemogram and CSF analysis) and pathological findings were retrieved.

The small ruminants and cattle were submitted to clinical exams according to the recommendations of Diffay et al. (2004) and Dirksen et al. (1993), respectively. Blood samples were collected from five animals in a vacuum tube containing EDTA anticoagulant $(10 \%)$ to perform hemogram, according to JAIN (1993). Cerebrospinal fluid (CSF) samples were collected aseptically from the cerebellomedullary cistern (cisterna magna) of six ruminants, before euthanasia in extremis (Isolated Case 1; Case 2 - Outbreak 1, and Case 5 - Outbreak $3)$ or immediately after spontaneous death (Cases 3 and 4 - Outbreak 2; Case 6 - Outbreak 3), and then analyzed according to the method proposed by $\operatorname{SCOTT}(2004,2010)$. These CSF samples were immediately assessed after collection. Erythrocyte and leukocyte counts were performed using a Neubauer chamber. For cytological and leukocyte differential examinations, a cell concentrate smear was obtained by centrifugation and stained with Panótico $^{\mathrm{TM}}$ (NewProv InstantProv, Pinhais - PR, Brazil). Density was obtained with the aid of a clinical refractometer (Quimis, Diadema - SP, Brazil). CSF aliquots were seeded in defibrinated sheep blood agar $(5 \%)$ for microbiological culturing, followed by microaerophilic incubation in a bacteriological oven at $37^{\circ} \mathrm{C}$ for 48 hours.

Two ruminants treated in the hospital routine (Cases 3 and 4 - Outbreak 2) and those animals with initial symptoms in the respective farms were submitted to clinical therapy by administering thiamine (10 mg.kg-1; q6h; intravenously [IV], 
minimum of three days), dexamethasone (0.5 mg.kg ${ }^{-1} ;$ q24h; IV, three days), and hydroelectrolytic correction. We also investigated the possible PEM etiology by means of detailed anamnesis with the farm owners and visiting the farms.

\section{Results}

Table 1 shows epidemiological data and clinical evolution. After anamnesis with the owners, four cases of PEM (Cases 1-4) were associated with chronic ruminal lactic acidosis caused by a diet rich in fast-fermenting carbohydrate, containing mainly concentrates, ground soybean hulls and melon. The first case involved a six-month-old sheep (Isolated Case 1) reared as a ruminant pet in the backyard of the owner's residence in Mossoró-RN. This sheep was fed almost exclusively corn and wheat bran, and had limited access to bulky food in the last two months. The animal was submitted to clinical examination; after two days' evolution, it presented lateral decubitus with limb spasticity, no responses to external stimuli, bilateral blindness, opisthotonus, and paddling (comatose). Necropsy revealed vessel congestion and cerebral edema, with caudal displacement and herniation of the cerebellum through the foramen magnum. The histological changes were characterized by laminar neuronal necrosis in the cerebral cortex, neurons with increased eosinophilia in the perikaryon, chromatolysis, and nuclear pyknosis. We also observed endothelial hyperplasia with mononuclear inflammatory infiltrate, mild multifocal gliosis, and focal neuronal necrosis in some thalamic nuclei.

Table 1. Epidemiology and clinical evolution of six ruminants with polioencephalomalacia in Rio Grande do Norte state, Brazil.

\begin{tabular}{|c|c|c|c|c|c|c|c|}
\hline Identification & Description & Age & Outbreak & $\begin{array}{l}\text { Clinical } \\
\text { evolution }{ }^{\mathrm{a}} \\
\text { (days) }\end{array}$ & $\begin{array}{c}\text { Morbidity } \\
(\%)\end{array}$ & $\begin{array}{c}\text { Mortality } \\
(\%)\end{array}$ & Town \\
\hline Isolated Case 1 & $\begin{array}{c}\text { Half-bred } \\
\text { ewe }\end{array}$ & 6 months & No & 2 & $50(1 / 2)$ & $50(1 / 2)$ & Mossoró \\
\hline Case2 (Outbreak 1) & $\begin{array}{c}\text { Nellore } \\
\text { Heifer }\end{array}$ & 2 years & Yes & 1 & $13.3(6 / 45)$ & $2.2(1 / 45)$ & Tibau \\
\hline Case 3 (Outbreak 2) & $\begin{array}{c}\text { Half-bred } \\
\text { ewe }\end{array}$ & 4 years & Yes & 3 & $30.7(8 / 26)$ & $15.3(4 / 26)$ & Mossoró \\
\hline Case 4 (Outbreak 2) & $\begin{array}{c}\text { Half-bred } \\
\text { ewe }\end{array}$ & 18 months & Yes & 3 & $30.7(8 / 26)$ & $15.3(4 / 26)$ & Mossoró \\
\hline Case 5 (Outbreak 3) & $\begin{array}{l}\text { Morada } \\
\text { Nova ewe }\end{array}$ & 3 years & Yes & 1 & $8.1(15 / 183)$ & $8.1(15 / 183)$ & Areia Branca \\
\hline Case 6 (Outbreak 3) & $\begin{array}{c}\text { Half-bred } \\
\text { goat }\end{array}$ & 4 years & Yes & 1 & $8.1(15 / 183)$ & $8.1(15 / 183)$ & Areia Branca \\
\hline
\end{tabular}

${ }^{\text {a}}$ Elapsed time from observation of clinical symptoms by the owner until veterinary care.

The disease occurred as an outbreak on a farm with extensive Nellore breeding system, located in Tibau-RN (Outbreak 1). The affected batch consisted of 45 heifers reared in Brachiaria brizantha pasture, and fed a supplemented diet with abundant melon in the trough. One of the heifers was found in lateral decubitus with paddling movements but received no treatment. On the next day, five other heifers presented dysmetria, lethargy, hyporexia and decreased visual acuity. In view of these new cases, the owner referred the heifer which first showed clinical signs (Case 2 - Outbreak 1) for hospital care. Thus, the clinical evaluation was performed $48 \mathrm{~h}$ after finding the heifer in lateral decubitus in the pasture, observing severe dehydration, enophthalmos, bilateral blindness, 
sporadic paddling movements, and no responses to external stimuli. Given the clinical suspicion of PEM, the aforementioned therapy was instituted in the five heifers of the batch with initial clinical signs, which then obtained total recovery. Another recommended measure was adjustment of the herds' diet without new cases. The macroscopic findings from the necropsied heifer (Case 2 Outbreak 1) showed changes resulting from the long decubitus period, such as sores at various body regions and pulmonary hypostasis. Histological examination revealed telencephalic cortex, mainly in the temporal and parietal lobes, with laminar and segmental neuronal necrosis, characterized by marked cytoplasmic acidophilus, nuclear pyknosis and cell shriveling (red neurons). Moderate to severe vacuolation of the perineuronal and perivascular spaces, and the neuropil was also observed.

Another PEM outbreak occurred in Mossoró$\mathrm{RN}$, affecting a herd of intensively raised sheep (Outbreak 2). The owner confirmed seven out of eight ewes from the flock presented ataxia, rigid walking, and blindness after 5 to 7 days. These flock was raised on a walled lot $\left(1,000 \mathrm{~m}^{2}\right)$ with access only to native pasture and supplementation with ground soybean hulls at will in the last month. Two ewes died on the property and were not assessed. Two other severely affected ewes were referred for clinical examination and hospital admission (Cases 3 and 4 - Outbreak 2) and presented a six-day evolution. Clinical examination revealed lateral decubitus with paddling movements, severe dehydration, teeth grinding, nystagmus, bilateral blindness, tachycardia, and ruminal hypomotility. These two ewes and four other sheep on the farm were submitted to clinical therapy, with the recovery of those presenting initial symptomatology (ruminants still remained standing). The two hospitalized ewes died and were necropsied, presenting macroscopic alterations, cerebral edema, and caudal displacement of the cerebellum. Also, the cut surface of the cerebral cortex showed areas of yellowish coloration with a decrease in consistency, suggesting malacia. Main histological alterations occurred in the telencephalic, occipital, temporal, parietal and frontal lobes, with laminar and segmental neuronal necrosis, spongiosis, nuclear pyknosis and moderate neutrophil and eosinophil infiltrate. The presence of large macrophage infiltrates with foamy cytoplasm (Gitter cells) was striking. The cerebellum showed degeneration and moderate disappearance of Purkinje cells.

PEM lesion was also observed in small ruminants with spontaneous petroleum poisoning (BATISTA et al., 2013). In Areia Branca-RN, there was a mortality outbreak in sheep and goats (Outbreak 3 ). The total of 15 ruminants (14 sheep and one goat) died within two days. The owner reported that the flock was extensively reared without mineral supply and was apparently healthy. Upon visiting the farm, we found that ruminants had access to a single drinking fountain in the extensive property, but there were several wells for oil extraction with the cemented base, where there was an accumulation of water mixed with crude oil. Two recently dead ruminants (one ram and one goat) and one dying ewe were referred for pathological diagnosis. The ewe was submitted to clinical examination (Case 5 - Outbreak 3), which showed lateral decubitus with paddling movements, mydriasis, bilateral blindness, cyanotic mucosae, severe dehydration, tachycardia, mixed dyspnea, atony and ruminal tympanism. The total of three ruminants was necropsied, and a CSF sample of the recently dead goat (Case 6 - Outbreak 3 ) was also collected for laboratory evaluation.

At necropsy of the small ruminants from Outbreak 3, macroscopic findings included extensive subcutaneous edema, congested and swollen lungs; hepatic, splenic and renal congestion. The gastrointestinal tract had a strong odor similar to gasoline, more intense inside the rumen and abomasum. We also noted diffuse mucosal hyperemia of the rumen and reticulum, with an easy detachment of the mucosa. Case 5 (Outbreak 3) also presented subdural hemorrhages in the dorsal portion of the brain and brain stem probably due to 
trauma from falls. The brain was pale with severe edema, flattening of the convolutions, and narrowing of the sulci. Cerebellum was displaced caudally with herniation through the foramen magnum. The cut surface of the cerebral cortex showed areas with blackened coloration and softened consistency. Histopathological examination revealed toxic tubular nephrosis, characterized by degeneration and necrosis of the tubular epithelium, and the presence of intratubular cylinders and inclusion corpuscles. In the heart, there was extensive bleeding foci, edema and coagulation necrosis of cardiac fibers. The liver had foci of hepatocyte necrosis, megalocytosis, severe sinusoidal congestion and accumulation of biliary pigment in the hepatic parenchyma. Rumen and reticulum presented hydropic degeneration of the epithelial cells. In the cerebellum, we found degenerate Purkinje cells characterized by eosinophilic retraction and chromatolysis. Lesions in the telencephalic cortex were characterized by segmental laminar neuronal necrosis with acidophilic cytoplasm and pyknotic nuclei (red neurons), cytoplasmic vacuoles, gliosis, and perineural and perivascular swelling (Figure 1). We also observed infiltrates of foamy macrophages (Gitter cells) in the telencephalic cortex, with the formation of a cystic area between the white matter and the leptomeninges (residual lesion). Thalamic nuclei also presented laminar and segmental neuronal necrosis and the presence of basophilic, homogeneous and hyaline clots with chromatin displaced to the cellular periphery, suggesting inclusion corpuscles.

Figure 1. Sheep cerebral cortex intoxicated with petroleum, presenting segmental laminar neuronal necrosis, spongiosis and nuclear pyknosis (HE staining, 40x magnifying lens).

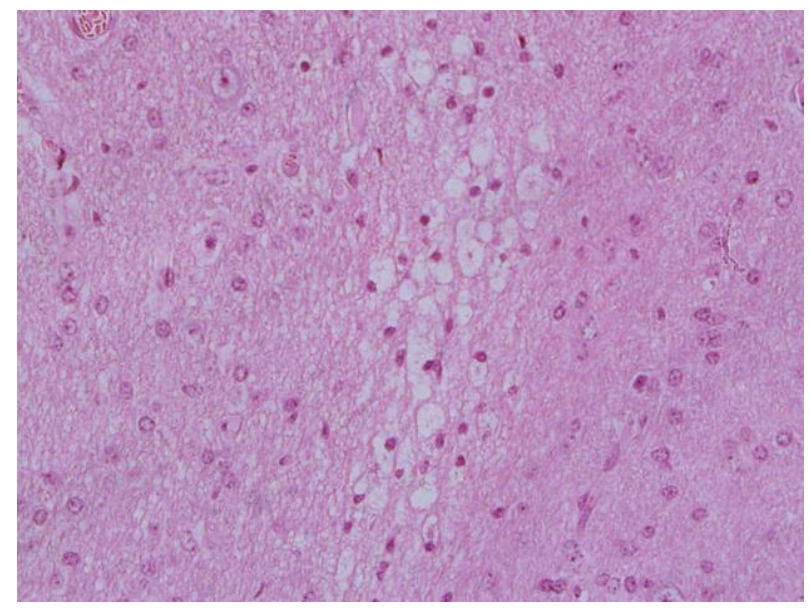

Clinical pathology tests were performed on five ruminants, and the hematological findings are presented in Table 2. Neutrophilia (Cases 1 and 5) and absolute monocytosis (Case 5) were observed. One ruminant had normocytic-normochromic anemia associated with hypoproteinemia (Case 3). CSF analysis (Table 3) revealed higher or increased
$(>1.010)$ density in four of the six cases $(66.7 \%)$. Leukocytes remained within the physiological limits, reaching a maximum of 9 leukocytes $/ \mu \mathrm{L}$. Sporadic changes such as reddish coloration (Case 3), xanthochromia (yellowish coloration - Case 5), and formation of fibrin clot (Case 5) were also observed. Microbiological culture of CSF samples was negative for bacterial growth. 
Table 2. Hematological and total plasma protein values in five ruminants with polioencephalomalacia.

\begin{tabular}{ccccccc}
\hline Parameters & $\begin{array}{c}\text { Isolated } \\
\text { case 1 }\end{array}$ & $\begin{array}{c}\text { Case 2 } \\
(\text { Outbreak 1) }\end{array}$ & $\begin{array}{c}\text { Case 3 } \\
\text { (Outbreak 2) }\end{array}$ & $\begin{array}{c}\text { Case 4 } \\
\text { (Outbreak 2) }\end{array}$ & $\begin{array}{c}\text { Case 5 } \\
\text { (Outbreak 3) }\end{array}$ & Reference $^{\text {a }}$ \\
\hline Hematocrit $(\%)$ & 43 & 39 & 23 & 36 & 42 & $24-50$ \\
RBCs $\left(\times 10^{6} / \mu \mathrm{L}\right)$ & 12.3 & 7.1 & 10.1 & 10.8 & 16.8 & $8-16$ \\
Hemoglobin $(\mathrm{g} / \mathrm{dL})$ & 13.4 & 12.6 & 7.4 & 11.6 & 13.5 & $8-16$ \\
Mean corpuscular volume $(\mathrm{fL})$ & 35 & 55 & 24 & 33 & 25 & $23-48$ \\
Total leukocytes $(/ \mu \mathrm{L})$ & 11,100 & 4,500 & 4,900 & 5,000 & 10,900 & $4,000-12,000$ \\
Segmented Neutrophils $(/ \mu \mathrm{L})$ & 8,103 & 2,340 & 3,479 & 3,800 & 8,175 & $400-6,000$ \\
Lymphocytes $(/ \mu \mathrm{L})$ & 2,220 & 1,845 & 1127 & 950 & 1,853 & $1,600-9,000$ \\
Monocytes $(/ \mu \mathrm{L})$ & 444 & 225 & 245 & 200 & 763 & $40-720$ \\
Eosinophils $(/ \mu \mathrm{L})$ & 333 & 45 & 49 & 50 & 109 & $40-1.200$ \\
Band $(/ \mu \mathrm{L})$ & 0 & 45 & 0 & 0 & 0 & 0 \\
Total Proteins $(\mathrm{g} / \mathrm{dL})$ & 6.2 & $\mathrm{ND}^{\mathrm{b}}$ & 4 & 6.6 & 7 & $6.0-7.9$ \\
\hline
\end{tabular}

${ }^{a}$ KRAMER (2000)

${ }^{\mathrm{b}} \mathrm{ND}$ : not determined.

Table 3. Microbiological analysis and culture in cerebrospinal fluid in six ruminants with polioencephalomalacia.

\begin{tabular}{cccccccc}
\hline $\begin{array}{c}\text { Parameter } \\
\text { Case }\end{array}$ & Color & $\begin{array}{c}\text { Fibrin } \\
\text { reticulum }\end{array}$ & $\begin{array}{c}\text { Microbiological } \\
\text { Culture }\end{array}$ & Density & $\begin{array}{c}\text { Glucose } \\
(\mathrm{mg} / \mathrm{dL})\end{array}$ & $\begin{array}{c}\text { RBCs } \\
(/ \mu \mathrm{L})\end{array}$ & $\begin{array}{c}\text { Leukocytes } \\
(/ \mu \mathrm{L})\end{array}$ \\
\hline Isolated1 & Colorless & Absent & Negative & 1.010 & $\mathrm{ND}^{\mathrm{b}}$ & 44 & 6 \\
$2($ Outbreak 1) & Colorless & Absent & Negative & 1.010 & 50 & 105 & 4 \\
3 (Outbreak 2) & Reddish & Absent & Negative & 1.005 & 60 & 1,005 & 3 \\
$4($ Outbreak 2) & Colorless & Absent & Negative & 1.005 & 70 & 21 & 2 \\
$5($ Outbreak 3) & Yellowish & Present & Negative & 1.030 & $\mathrm{ND}$ & 450 & 9 \\
$6($ Outbreak 3) & Colorless & Absent & Negative & 1.020 & 50 & 220 & 6 \\
Reference $^{\mathrm{a}}$ & Colorless & Absent & Negative & $<1.010$ & $35-70$ & Rare & $<10$ \\
\hline
\end{tabular}

a $\operatorname{SCOTT}(2004,2010)$

${ }^{\mathrm{b}} \mathrm{ND}$ : not determined.

\section{Discussion}

Definitive diagnosis of PEM was based on the association of epidemiological data and clinical, laboratorial, and mainly pathological findings, thus confirming the occurrence of this disease in the semi-arid region of Rio Grande do Norte. One of the recognized causes of PEM in ruminants is thiamine deficiency demonstrated by low concentrations of this vitamin in the brain and liver of affected cattle and sheep (GOULD, 1998). This deficiency may be a consequence of chronic ruminal lactic acidosis due to carbohydrate-rich diets, since the transition period for adaptation of the ruminal microbiota may take up to 21 days (LIMA et al., 2012). Low ruminal $\mathrm{pH}$ conditions may not only render the environment unfavorable to thiaminesynthesizing microorganisms, but also improve the propagation conditions for thiaminase-producing bacteria, such as Clostridium sporogenes and Bacillus thiaminollyticus (HAVEN et al., 1983), and thus compromising the availability of this vitamin. After the thiamine hepatic reserve is reduced, the deficiency condition is established, with clinical manifestations mainly in the nervous system because of the interference with aerobic glycolysis and consequent ATP formation (GOULD, 1998; SANT'ANA et al., 2009b; GRAÇA et al., 2010).

The supply of unusual foods, such as soybean hulls, may promote imbalance of ruminal microbiota since this food has medium effective degradability 
and high dry matter digestibility, similar to corn and wheat bran, and is also capable of promoting ruminal acidosis (ZAMBOM et al., 2001). Recent studies have shown that diets rich in melon, which was associated to PEM in Nellore heifers (Outbreak 1), can induce rumen acidosis by their high concentrations of saccharides (OLIVEIRA et al., 2015), and could probably trigger thiamin deficiency. In fact, sucrose is routinely used for experimental induction of ruminal lactic acidosis (MIRANDA NETO et al., 2005), possibly triggering the disturbance in the ruminal microbiota described above.

In the PEM outbreak due to petroleum poisoning (Outbreak 3 - Cases 5 and 6), the disease was attributed to the ingestion of residues present in the accumulated production water in the cemented bases of the oil extraction wells (COPPOCK; CHRISTIAN, 2007). Due to seasonal water shortages, the ingestion of this water may induce salt intoxication or, alternatively, high levels of sulfates. The consumption of sulfate-rich water by ruminants increases the risk of thiamine-responsive PEM (GOULD, 1998), and sulfur intoxication (EDWARDS; GREGORY, 1991; COPPOCK; CHRISTIAN, 2007). Severe macro and microscopic lesions in the two sheep and one goat of Outbreak 3 are consistent with changes of malacia and edema in deep structures of the encephalon described in ruminants with PEM associated to sulfur intoxication (LONERAGAN et al., 1998; CUNHA et al., 2010). Moreover, the lack of salt or mineral mixture supplementation associated with the absence of eosinophilic infiltrate in the CNS allows us to rule out the hypothesis of salt intoxication, since this lesion is considered pathognomonic of this toxicosis, especially in swine (CEBRA; CEBRA, 2004; BRUM et al., 2013). Thus, the production water being rich in sulfur (COPPOCK; CHRISTIAN, 2007) together with the pathological findings strongly suggests that these cases of PEM are caused by sulfur intoxication.
The morbidity and mortality coefficients presented a variation of $8.1-50 \%$ and $50-100 \%$, respectively. In other studies, considering the total population for calculation, the authors indicate the morbidity of $0.02-14.28 \%$ (NAKAZATO et al., 2000); 0.04-6.66\% (SANT'ANA et al., 2009a); 1220\% (LIMA et al., 2005); and 8.34-38.76\% (RIBAS et al., 2013). Highest morbidity in the present study was observed in Isolated Case 1, which belonged to a herd of only two sheep. Excluding this case, the morbidity ranged from 8.1 to $30.7 \%$, which is a range close to that reported in the other outbreaks. The case-fatality rates described in the literature ranged from 48.5-100\% (NAKAZATO et al., 2000), 50-100\% (SANT'ANA et al., 2009a; RIBAS et al., 2013), and 66.6- 100\% (LIMA et al., 2005), is similar to those obtained herein. Results of CSF analysis showed a density above the physiological parameters or in the upper limit for four cases. This finding is considered non-specific and of low precision for the investigation of the cause of neurological diseases in ruminants (SCOTT, 2004, 2010). The presence of increased density is an unusual finding in ruminants with PEM, since only the presence of normal protein concentrations and mild lymphocytic pleocytosis are the described changes (SCOTT, 2004, 2010). Just as the cases reported here, Stokol et al. (2009) demonstrated that $75 \%$ of the bovines with PEM showed no pleocytosis; this finding was also described for calves with PEM experimentally induced by sulfur administration (CUNHA et al., 2011). The alteration of reddish coloration of CSF observed in a sample (Case 3) can be attributed to blood contamination due to an accidental trauma of the leptomeningeal vessels during collection. Xanthochromia (Case 5) is observed a few hours after subarachnoid hemorrhage, possibly caused by trauma, and may persist for two to four weeks (SCOTT, 2004); which is consistent with the history of falls and macroscopic findings of subdural hematomas. The presence of fibrin clots in the CSF is indicative of bacterial contamination (CÂMARA et al., 2014a), however, 
there was no growth of microorganisms after sample culturing, which may be explained by the increase in protein concentration (STOKOL et al., 2009). Hence, it is worth associating CSF analysis with epidemiological, clinical, and pathological findings, mainly as the results described here are similar to those reported in cases of toxic diseases such as botulism (CÂMARA et al., 2014b).

\section{Conclusions}

Polioencephalomalacia cases described in this study were associated with thiamine deficiency caused by chronic ruminal lactic acidosis, derived from a high-carbohydrate diet and excessive sulfur intake due to oil poisoning.

\section{References}

ADAMS, O. R.; GRINER, L. A.; JENSEN, R. Polioencephalomalacia of cattle and sheep. Journal of the American Veterinary Medical Association, Ithaca, v. 129, n. 7, p. 311-321, 1956.

BATISTA, J. S.; CÂMARA, A. C. L.; ALMEIDA, R. D.; OLINDA, R. G.; SILVA, T. M. F.; SOTO-BLANCO, $\mathrm{B}$. Poisoning by crude oil in sheep and goats. Revue de Médecine Vétérinaire, Toulouse, v. 164, n. 11, p. 517520, 2013.

BRUM, J. S.; GALIZA, G. J. N.; LUCENA, R. B.; BARROS, C. S. L. Intoxicação por sal em suínos: aspectos epidemiológicos, clínicos e patológicos e breve revisão de literatura. Pesquisa Veterinária Brasileira, Seropédica, v. 33, n. 7, p. 890-900, 2013.

CÂMARA, A. C. L.; OLIVEIRA, C. M. M.; VALE, A. M.; BATISTA, J. S.; SOTO-BLANCO, B. Epidemiologia, sinais clínicos, achados laboratoriais e patológicos em oito surtos de botulismo em bovinos no Rio Grande do Norte. Acta Scientiae Veterinariae, Porto Alegre, v. 42, art. 1200, p.1-8, 2014b.

CÂMARA, A. C. L.; VALE, A. M.; BATISTA, J. S.; FEIJÓ, F. M. C.; SOTO-BLANCO, B. Suppurative intracranial processes in 15 domestic ruminants. Pesquisa Veterinária Brasileira, Seropédica, v. 34, n. 5, p. 421426, 2014a.

CEBRA, C. K.; CEBRA, M. L. Altered mentation caused by polioencephalomalacia, hypernatremia, and lead poisoning. Veterinary Clinics of North America: Food
Animal Practice, Philadelphia, v. 20, n. 2, p. 287-302, 2004.

COPPOCK, R. W.; CHRISTIAN, R. G. Petroleum. In: GUPTA, R. C. (Ed.). Veterinary toxicology: basic and clinical principles. New York: Academic Press, 2007. p. 615-639.

CUNHA, P. H. J.; BADIAL, P. R.; CAGNINI, D. Q.; OLIVEIRA FILHO, J. P.; MORAES, L. F.; TAKAHIRA, R. K.; AMORIM, R. L.; BORGES, A. S. Polioencefalomalacia experimental em bovinos induzida por toxicose por enxofre. Pesquisa Veterinária Brasileira, Seropédica, v. 31, n. 1, p. 41-52, 2011.

CUNHA, P. H. J.; BANDARRA, P. M.; DIAS, M. M.; BORGES, A. S.; DRIEMEIER, D. Surto de polioencefalomalacia por ingestão excessiva de enxofre na dieta em bezerros no Rio Grande do Sul. Pesquisa Veterinária Brasileira, Seropédica, v. 30, n. 8, p. 613$617,2010$.

DELFIOL, D. J. Z.; CAGNINI, D. Q.; CUNHA, P. H. J.; CROSIGNANI, N.; WOUTERS, A. T. B.; WOUTERS, F.; DRIEMEIER, D.; BORGES, A. S. Aspectos clínicos e laboratoriais em ovinos submetidos a dietas com níveis elevados de enxofre com objetivo de indução de polioencefalomalacia. Pesquisa Veterinária Brasileira, Seropédica, v. 33, n. 4, p. 435-442, 2013.

DIFFAY, B. C.; MCKENZIE, D.; WOLF, C.; PUGH, D. G. Abordagem e exame de ovinos e caprinos. In: PUGH, D. G. (Ed.). Clínica de ovinos e caprinos. São Paulo: Roca, 2004. p. 1-19.

DIRKSEN, G.; GRÜNDER, H. -D.; STÖBER, M. Rosenberger, exame clínico dos bovinos. 3. ed. Guanabara Koogan: Rio de Janeiro, 1993. 419 p.

DUARTE, M. D.; BEZERRA JÚNIOR, P. S.; LIMA, D. H. S.; BOMJARDIM, H. A.; OLIVEIRA, C. M. C.; SILVA, N. S.; FAIAL, K. C. F.; BARBOSA, J. D. Surto de intoxicação por sal em ovinos no estado do Pará. Pesquisa Veterinária Brasileira, Seropédica, v. 34, n. 11, p. 1061-1068, 2014.

EDWARDS, W. C.; GREGORY, D. G. Livestock poisoning from oil field drilling fluids, muds and additives. Veterinary and Human Toxicology, Manhattan, v. 33 , n. 5 , p. $502-504,1991$.

GOULD, D. H. Polioencephalomalacia. Journal of Animal Science, Champaign, v. 76, n. 1, p. 309-314, 1998.

GRAÇA, D. L.; ALESSI, A. C.; ECCO, R.; VIOTT, A. M. Patologia do sistema nervoso. In: SANTOS, R. L.; ALESSI, A. C. Patologia veterinária. São Paulo: Roca, 2010. p. 525-610. 
GUIMARÃES, E. B.; LEMOS, R. A. A.; NOGUEIRA, A. P. A.; SOUZA, A. C. Ocorrência natural de polioencefalomalácia em búfalos Murrah (Buballis bubalis) mantidos em pastagem de gramínea consorciada com leguminosa em fase de rebrota, em MS. In: ENCONTRO NACIONAL DE DIAGNÓSTICO VETERINÁRIO, 2008, Campo Grande. Anais... Campo Grande: UFMS, 2008. p. 227-228.

HAVEN, T. R.; CALDWELL, D. R.; JENSEN, R. Role of predominant rumen bacteria in the cause of polioencephalomalacia (cerebrocortical necrosis) in cattle. American Journal of Veterinary Research, Schaumburg, v. 44, n. 8, p. 1451-1455, 1983.

JAIN, N. C. Essentials of veterinary hematology. Philadelphia: Lea and Febinger, 1993. 417 p.

KRAMER, J. W. Normal hematology of cattle, sheep and goats. In: FELDMAN, B. F.; ZINKL, J. G.; JAIN, N. C. Schalm's veterinary hematology. $5^{\text {th }}$ ed. Philadelphia: Lippincott Williams and Wilkins, 2000. p. 1075-1084.

LEMOS, R. A. A.; DRIEMEIER, D.; GUIMARÃES, E. B.; DUTRA, I. S.; MORI, A. E.; BARROS, C. S. L. Lead poisoning in cattle grazing pasture contaminated by industrial waste. Veterinary and Human Toxicology, Manhattan, v. 46, n. 6, p. 326-328, 2004.

LIMA, E. F.; RIET-CORREA, F.; TABOSA, I. M.; DANTAS, A. F. M.; MEDEIROS, J. M.; SUCUPIRA JÚNIOR, G. Polioencefalomalacia em caprinos e ovinos na região semiárida do Nordeste do Brasil. Pesquisa Veterinária Brasileira, Seropédica, v. 25, n. 1, p. 9-14, 2005.

LIMA, M. E.; VENDRAMIN, L.; HOFFMANN, D. A. C.; LISBOA, F. P.; GALlinA, T.; RABASSA, V. R.; SCHWEGLER, E.; CÔRREA, M. N. Alterações na população de protozoários ruminais, quantificados a partir da adaptação da técnica de Dehority, de ovinos submetidos a uma dieta de confinamento. Acta Scientiae Veterinariae, Porto Alegre, v. 40, n. 1, 2012.

LONERAGAN, G. H.; GOULD, D. H.; CALLAN, R. J.; SIGURDSON, C. J.; HAMAR, D. W. Association of excess sulfur intake and an increase in hydrogen sulfide concentrations in the ruminal gas cap of recently weaned beef calves with polioencephalomalacia. Journal of the American Veterinary Medical Association, Ithaca, v. 213, n. 11, p. 1599-1604, 1998.

MIRANDA NETO, E. G.; AFONSO, J. A. B.; MENDONÇA, C. L.; ALMEIDA, M. Z. P. R. B. Estudo clínico e características do fluido ruminal de caprinos com acidose láctica induzida experimentalmente. Pesquisa Veterinária Brasileira, Seropédica, v. 25, n. 2, p. 73-78, 2005.
NAKAZATO, L.; LEMOS, R. A. A.; RIET-CORREA, F. Polioencefalomalacia em bovinos nos estados de Mato Grosso do Sul e São Paulo. Pesquisa Veterinária Brasileira, Seropédica, v. 20, n. 3, p. 119-125, 2000.

NOGUEIRA, A. P. A.; SOUZA, R. I. C.; SANTOS, B. S.; PINTO, A. P.; RIBAS, N. L. K. S.; LEMOS, R. A. A.; SANT'ANA, F. J. F. Polioencefalomalacia experimental induzida por amprólio em bovinos. Pesquisa Veterinária Brasileira, Seropédica, v. 30, n. 8, p. 631-636, 2010.

OLIVEIRA, F. L. C.; BARRÊTO-JUNIOR, R. A.; MINERVINO, A. H. H.; REIS, L. F.; TAVARES, M. D.; VALE, R. G.; GAMELEIRA, J. S.; SOUZA, F. C. A.; MORI, C. S.; ORTOLANI, E. L. Clinical evaluation of unadapted sheep submited to sudden intake of melon with high levels of sugar. Semina: Ciências Agrárias, Londrina, v. 36, n. 6, p. 3721-3730, 2015.

OSWEILER, G. D.; CARR, T. F.; SANDERSON, T. P.; CARSON, T. L.; KINKER, J. A. Water deprivationsodium ion toxicosis in cattle. Journal of Veterinary Diagnostic Investigation, Columbia, v. 7, n. 4, p. 583585, 1995

RIBAS, N. L. K. S.; CARVALHO, R. I.; SANTOS, A. C.; VALENÇOELA, R. A.; GOUVEIA, A. F.; CASTRO, M. B.; MORI, A. E.; LEMOS, R. A. A. Doenças do sistema nervoso de bovinos no Mato Grosso do Sul: 1082 casos. Pesquisa Veterinária Brasileira, Seropédica, v. 33, n. 10, p. 1183-1194, 2013.

SANT'ANA, F. J. F.; LEMOS, R. A. A.; NOGUEIRA, A. P. A.; TOGNI, M.; TESSELE, B.; BARROS, C. S. L. Polioencefalomalacia em ruminantes. Pesquisa Veterinária Brasileira, Seropédica, v. 29, n. 9, p. 681694, 2009b.

SANT'ANA, F. J. F.; NOGUEIRA, A. P. A.; SOUZA, R. I. C.; CARDINAL, S. G.; LEMOS, R. A. A.; BARROS, C. S. L. Polioencefalomalacia experimental induzida por amprólio em ovinos. Pesquisa Veterinária Brasileira, Seropédica, v. 29, n. 9, p. 747-752, 2009a.

SCOTT, P. R. Cerebrospinal fluid collection and analysis in suspected sheep neurological disease. Small Ruminant Research, Amsterdam, v. 92, n. 1-3, p. 96-103, 2010.

Diagnostic techniques and clinicopathologic $\overline{\text { findings }}$ in ruminant neurologic disease. Veterinary Clinics of North America: Food Animal Practice, Philadelphia, v. 20, n. 2, p. 215-230, 2004.

STOKOL, T.; DIVERS, T. J.; ARRIGAN, J. W.; MCDONOUGH, S. P. Cerebrospinal fluid findings in cattle with central nervous system disorders: A retrospective study of 102 cases (1990-2008). Veterinary Clinical Pathology, Baton Rouge, v. 38, n. 1, p. 103-112, 2009. 
VIEIRA, A. C. S.; AFONSO, J. A. B.; TOKARNIA, ZAMBOM, M. A.; SANTOS, G. T.; MODESTO, E. C.; C. H.; COSTA, N. A.; MENDONÇA, C. L.; SOUZA, ALCALDE, C. R.; GONÇALVES, G. D.; SILVA, D. M. I. Estudo epidemiológico, clinico e patológico em ruminantes com polioencefalomalacia no Agreste Meridional de Pernambuco. Revista Brasileira de C.; SILVA, K. T.; FAUSTINO, J. A. Valor nutricional da casca do grão de soja, farelo de soja, milho moído e farelo de trigo para bovinos. Acta Scientiarum, Animal Medicina Veterinária, Rio de Janeiro, v. 29, n. 2, p. 6568, 2007. 